\title{
Antifeedant and allelopathic activities of the hydroalcoholic extract obtained from Neem (Azadirachta indica) leaves
}

\author{
José de Paula da Silva, Antonio Eduardo Miller Crotti, Wilson Roberto Cunha* \\ Núcleo de Pesquisas em Ciências Exatas e Tecnológicas, Universidade de Franca, \\ Av. Dr. Armando Salles de Oliveira 201, 14404-600, Franca, SP, Brazil
}

\begin{abstract}
RESUMO: “Atividades antialimentar e alelopática do extrato hidroalcoólico obtido das folhas de Nim (Azadirachta indica)". A espécie vegetal Azadirachta indica, popularmente chamada de Nim, é conhecida em muitos países devido a suas inúmeras propriedades biológicas. O presente estudo teve como objetivo investigar a propriedade antialimentar do extrato hidroalcoólico das folhas de Nim sobre Zabrotes fasciatus (Coleoptera: Bruchidae), um inseto conhecido como carucho-do-feijão e que atua como praga durante o processo de estocagem do feijão comum (Phaseolus vulgaris). Este inseto provoca danos tais como perda de peso, redução do valor nutritivo e do grau de higiene do feijão. Quando adicionado a sua dieta, usando sementes de Phaseolus vulgaris, o extrato hidroalcoólico das folhas de Nim demonstrou efeito antialimentar, ocasionando assim, uma significativa redução nos danos. Os efeitos inibitórios deste extrato sobre a germinação e o crescimento de Phaseolus vulgaris também foram avaliados. O extrato de Nim afetou a germinação das sementes e o crescimento das radículas de Phaseolus vulgaris de uma maneira dose-dependente.
\end{abstract}

Unitermos: Azadirachta indica, Phaseolus vulgaris, Zabrotes fasciatus, Nim, atividade antialimentar, alelopatia.

\begin{abstract}
Azadirachta indica, the so-called Neem or Nim, is well-known for its biological activities in many countries. The present study aimed at investigating the antifeedant properties of the hydroalcoholic extract obtained from the leaves of Neem on Zabrotes fasciatus (Coleoptera: Bruchidae), an insect pest that commonly feeds on common bean (Phaseolus vulgaris) during seed storage. We observed that the hydroalcoholic extract obtained from Neem leaves displayed significant antifeedant activity when it was added to the insect diet via Phaseolus vulgaris seeds. Additionally, the inhibitory effects of this extract on Phaseolus vulgaris germination and growth were also evaluated, indicating that both seed germination and radicle growth were affected in a concentration-dependent manner.
\end{abstract}

Keywords: Azadirachta indica, Phaseolus vulgaris, Zabrotes fasciatus, Neem, antifeedant activity, phytogrowth activity.

\section{INTRODUCTION}

In many tropical and subtropical countries there are notable post-harvest losses of common bean, Phaseolus vulgaris L. (Fabaceae), due to bruchid pests, especially Zabrotes subsfasciatus (Coleoptera, Bruchidae) (Goossens et al., 2000). These insects are responsible for considerable weight reduction, decreased nutritional quality, and reduced seed germination power, not to mention the commercial depreciation of the beans because of the presence of adult or immature insects, fragments, or excrements in the seeds (Sari et al., 2003).

The indiscriminate use of synthetic pesticides for controlling $Z$. subsfasciatus has eventually led to an increase in the level of toxic residues in foodstuffs, as well as considerable environmental contamination. Thus, two great areas of interest have emerged, one dealing with bean genotype resistance to this insect (Schroeder et al., 1995; Goossens et al., 2000), and another one emphasizing the use of plant extracts to repel insect attack (Rembold, 1989; Viegas Jr, 2003).

Allelopatic compounds are chemical agents produced by a certain organism, to affect the health, growth, behavior, or population biology of organisms of other species (Engel; Pawlik, 2000). Recent studies have demonstrated that vegetable extracts and their constituents can affect the life cycle of some insects, and these same extracts can also interfere with the seed germination of some mono- and dicotyledoneous (Liu et al., 2002; Tawaha; Turk, 2003; Koul, 2004; Nasir et al., 2005; Dias et al., 2005; Fritz et al., 2007).

Azadirachta indica is an arboreal species originated from India, where it is known as "Neem". This plant is considered to be the "drugstore of the village" by the Indian population because of the large number of medicinal formulations that can be prepared from its 
active principles (Isman, 2000; Puri, 1999). A. indica seeds were introduced in Brazil in the 1970s, where it has been used as a phytochemical biopesticide (Martinez, 2002). Neem extracts and their biologically active constituents have been extensively studied because of their efficacy against a broad spectrum of pests, minimal toxicity, and rapid disappearance from the environment (Isman, 2000).

In this paper, the antifeedant activity of a hydroalcoholic extract obtained from Neem leaves on $Z$. subsfaciatus was evaluated. The effects of this extract on Phaseolus vulgaris seed germination and radicle growth were also investigated.

\section{MATERIAL AND METHODS}

\section{Plant material}

A. indica leaves were obtained from species cultivated under field conditions along three years. Seeds were kindly furnished by IAC (Instituto Agronômico de Campinas-SP, Brazil) and cultivated near Piumhi-MG.

\section{Extraction procedures}

A. indica leaves were air-dried at $40{ }^{\circ} \mathrm{C}$ and ground. The powdered material $(1.0 \mathrm{~kg})$ was exhaustively extracted by maceration with ethanol/water $4: 1(\mathrm{v} / \mathrm{v})$ for three weeks, at room temperature. Ethanol was removed by distillation under reduced pressure, and the remaining solution was lyophilized and stored under light protection, yielding $120 \mathrm{~g}$ of the crude hydroalcoholic lyophilized extract.

\section{Antifeedant assay}

Phaseolus vulgaris (common bean) seeds were treated with a $5 \%(\mathrm{w} / \mathrm{v})$ solution of the lyophilized extract obtained from $A$. indica (Neem) leaves in acetone. Twenty $P$. vulgaris seeds treated with the Neem extract were transferred to a Petri dish, which was then closed with a gauze and cork. After being treated with the extract, the seeds were stored in a glove box at room temperature until solvent evaporation. A Petri dish containing twenty $P$. vulgaris seeds treated with acetone only was used as negative control. After the evaporation of the solvent, twenty insects (Zabrotes subfasciatus) were added to each dish. The number of damaged seeds was counted on day thirty, to obtain the protection level.

\section{Allelopathic assay}

P. vulgaris seeds $(\mathrm{n}=20)$ were placed on filter paper (germitest $\left.{ }^{\circledR}\right)$ in Petri dishes ( $85 \mathrm{~mm}$ diameter). In

Table 1. Number of $P$. vulgaris seeds affected by Zabrotes subfasciatus after treatment with the hydroalcoholic extract of Azadirachta indica leaves.

\begin{tabular}{ccc}
\hline & Seeds $^{a}$ treated with Neem extract & \\
\hline Dish 1 & 2.0 & Negative control $^{\mathrm{c}}$ \\
Dish 2 & 2.0 & 20.0 \\
Dish 3 & 1.0 & 19.0 \\
Mean \pm S.E.M. & $1.7 \pm 0.3^{* * *}$ & 20.0 \\
\hline
\end{tabular}

a. Total number of seeds $=20 ; \mathrm{b} .5 \%(\mathrm{w} / \mathrm{v})$ in acetone; c. acetone

$* * * P<0.001$ (analysis of variance followed by Student's $t$-test)

Table 2. Percentage of germinated Phaseolus vulgaris seeds and their radicle length after treatment with a hydroalcoholic extract of Azadirachta indica leaves.

\begin{tabular}{cccc}
\hline Concentrations and treatments & Number of germinated seeds & Germinated seeds (\%) & Radicle length (mm) \\
\hline $25 \mathrm{mg} \mathrm{mL}^{-1}$ & $17.66 \pm 0.57$ & $88.33 \%$ & $19.98 \pm 11.68^{*}$ \\
$50 \mathrm{mg} \mathrm{mL}^{-1}$ & $10.33 \pm 0.57^{* *}$ & $51.67 \%$ & $6.18 \pm 6.57^{* *}$ \\
$100 \mathrm{mg} \mathrm{mL}^{-1}$ & $2.33 \pm 1.52^{* * *}$ & $11.67 \%$ & $0.63 \pm 1.77^{* * *}$ \\
$(+)$ control & $3.02 \pm 1.73^{* * *}$ & $15.00 \%$ & $0.95 \pm 2.35^{* * *}$ \\
$(-)$ control & $18.33 \pm 0.57$ & $91.67 \%$ & $65.76 \pm 32.73$ \\
\hline
\end{tabular}

Results expressed as mean \pm S.E.M. $(\mathrm{n}=20)$

$* P<0.05 * * P<0.01 \quad * * * P<0.001$ (analysis of variance followed by Student's $t$-test).

Positive control: herbicide glyphosate $\left(4 \mathrm{mg} \mathrm{mL}^{-1}\right)$. Negative control: distilled water. 
three replicated experiments, the paper was wetted with either deionized water (negative control) or the extract test solution. The treatments were undertaken using increasing extract concentrations $\left(25 \mathrm{mg} \mathrm{mL}^{-1}, 50 \mathrm{mg} \mathrm{mL}^{-1}\right.$ and $100 \mathrm{mg} \mathrm{mL}^{-1}$ ), with deionized water as solvent. An aqueous solution $\left(4 \mathrm{mg} \mathrm{mL}^{-1}\right)$ of the herbicide glyphosate (Roundup ${ }^{\circledR}$ ) was used as positive control. The dishes were wrapped in Parafilm foil and incubated at $25^{\circ} \mathrm{C}$, in the dark, for five days. Three replications were carried out for each germination assay. Control dishes contained the same number of seeds and the same solution volume. The number of germinated seeds was determined according to the criteria of $1 \mathrm{~mm}$ radicle extrusion. Radicle lengths were measured for all the germinated seeds.

\section{Statistics}

Data were statistically analyzed by variance analysis (ANOVA), with the significance level set at $P<$ 0.05 . Critical differences between means were evaluated by the Student's " $t$ " test.

\section{RESULTS}

\section{Antifeedant assay}

Table 1 shows the absolute number of $P$. vulgaris seeds affected by Zabrotes subfasciatus, for both the seeds treated with the hydroalcoholic extract obtained from $A$. indica leaves and those treated with acetone only (negative control). The counting was accomplished on day thirty, after $Z$. subfasciatus had completed its life cycle. Compared to the negative control, the number of affected seeds was significantly reduced when the hydroalcoholic extract obtained from $A$. indica leaves was incorporated into the medium.

\section{Phytogrowth assay}

Results on the P. vulgaris phytogrowth bioassays obtained after seed treatment with the Neem extract, as well as data acquired under negative (water) and positive (Roundup ${ }^{\circledR}$ ) conditions are shown in Table 2. Compared to the control, treating the seeds with the extract at a concentration of $25 \mathrm{mg} \mathrm{mL}^{-1}$ led to a percentage of seed germination equal to $88.33 \%$, similar to the value obtained under negative control conditions (91.67\%). However, the mean radicle length was significantly reduced when the extract was incorporated into the growth medium at different concentrations. The effects of the Neem extract on both the number of germinated seeds and the mean radicle length increased with increasing extract concentration, in a concentration-dependent manner.

\section{DISCUSSION}

The results obtained from the antifeedant assays clearly demonstrate that the hydroalcoholic extract obtained from $A$. indica leaves exerts antifeedant effects on $Z$. subfasciatus. The fact that the insect life cycle is not affected suggests that the extract causes an inhibition of the insect's ingestion ability, probably by making the beans unpalatable to them. A similar effect regarding appetite suppression was previously reported for Meliaceae plants (Koul, 2000; El-Aswad et al., 2004).

The crude hydroalcoholic extract obtained from $A$. indica leaves also exhibit inhibitory effects on P. vulgaris seed germination and radicle growth. These effects increase with extract concentration $(w / v)$, in a concentration-dependent manner. Inhibition of seed germination is similar to that obtained with the negative control (water) when an extract solution at a concentration of $25 \mathrm{mg} \mathrm{mL}^{-1}$ is used. However, inhibition of radicle growth at $100 \mathrm{mg} \mathrm{mL}^{-1}$ is similar to that achieved with the positive control (Roundup ${ }^{\circledR}$ ). These data suggest that the Neem extract not only inhibits seed germination, but it also interferes with post-emergence by influencing plantule growth and reducing radicle length.

The Neem crude hydroalcoholic extract completely dissolves in acetone (for the antifeedant assays) and water (for the phytogrowth assays), with no precipitated residues. This is strong evidence that chemical constituents of this extract are present in all the tested solutions and, therefore, they are the ones responsible for the deterrent effect on $Z$. subfasciatus as well as for the seed germination and radicle growth inhibitory activities on $P$. vulgaris. Limonoids, including azadiractin, have been isolated from different parts of Azadirachta sp (Isman, 2000). In fact, the ability of limonoids obtained from Cedrela ciliolata (Meliaceae) to affect the germination and post-emergent growth of mono- and dicotyledoneous has been previously reported (Céspedes et al., 1999). Thus, the antifeedant as well as the seeding germination and radicle growth inhibitory activities of the crude hydroalcoholic extract of $A$. indica leaves may be partially attributed to limonoids, but these activities can also be partly due to other compounds present in the leaves, which can be interacting synergistically or additively.

Thus, our findings suggest that this extract could play a crucial role in protecting $P$. vulgaris against $Z$. subsfasciatus and in preventing precocious seed germinaton under storage conditions. The Neem extract might not only be used as an alternative for the suppression of $Z$. subsfasciatus populations, but it can also be employed to induce postemergent herbicidal effects, taking advantage of the fact that it displays minimal mammalian toxicity (Isman, 1997).

\section{REFERENCES}

Céspedes CL, Caldeón JS, Gómez-Garibay F, Segura R, King-Diaz B, Lotina-Hennsen B 1999. Phytogrowth properties of limonoids isolated from Cedrela ciliolata. 
$J$ Chem Ecol 25: 2665-2676.

El-Aswad AF, Abdelgaleil SA, Nakatami M 2004. Feeding deterrent and growth inhibitory prperties of limonoids from Khaya senegalensis against cotton leafworm, Spodoptera littoralis. Pest Manag Sci 60: 199-203.

Engel S, Pawlik JR 2000. Allelopathic activities of sponge extracts. Mar Ecol-Prog Ser 207: 273-281.

Dias JFG, Círio GM, Miguel MD, Miguel OG 2005. Contribuição ao estudo alelopático de Maytenus ilicifolia Mart. ex Reiss., Celastraceae. Rev Bras Farmacogn 15: 220-223.

Fritz D, Bernardi AP, Haas JS, Ascoli BM, Bordignon SAL, von Poser G 2007. Germination and growth inhibitory effects of Hypericum myrianthum and $H$. polyanthemum extracts on Lactuca sativa L. Rev Bras Farmacogn 17: 44-48.

Goossens A, Quintero C, Dillen W, De Rycke R, Valor JF, De Clercq J, Van Montagu M, Cardona C, Angenon G 2000. Analysis of bruchid resistance in the wild common bean acessiob G02771: no evidence for insecticidal activity of arcelin 5. J Exp Bot 51: 1229-1236.

Isman MB 1997. Neem and other botanical insecticides: barriers to commercialization. Phytoparasitica 25: 339-344.

Isman MB 2000. Biopesticides based on phytochemical. In O. Koul, G. S. Dhaliwal, K. Koul (eds). Phytochemical Biopesticides. Overseas Publishers Association, Amsterdam.

Koul O, Jain MP, Sharma VK 2000. Growth inhibitory and antifeedant activity of extracts from Melia duabia to Spodoptera litura and Helicoverpa armigera larvae. Indian J Exp Biol 38: 63-68.

Koul O 2004. Biological activity of volatile di-n-propyl disulfide from seeds of neem, Azadirachta indica (Meliaceae), to two species of stored grain pests, Sitophilus oryzae (L.) and Tribolium castaneun (Herbst). JEcon Entomol 97: 1142-1147.

Liu ZL, Xu YJ, Wu J, Goh S, Ho SH 2002. Feeding deterrents from Dictamnus dasycarpus Turcz against two storedproduct insects. J Agric Food Chem 50: 1447-1450.

Martinez SS 2002. O Nim (Azadirachta indica): Natureza, Usos Múltiplos, Produção. IAPAR, Londrina.

Nasir H, Iqbal Z, Hiradate S, Fujii Y 2005.Allelopathic potential of Robinia pseudo-acacia L. J Chem Ecol 31: 2179-2192.

Puri HS 1999. Neem, The divine tree Azadirachta indica. Overseas Publishers Association, Amsterdam.

Rembold H 1989. Insecticides of Plant Origin. ACS Symposium. Series, 387: 150.

Sari LT, Ribeiro-Costa CS, Pereira PRVS 2003. Aspectos biológicos de Zabrotes subfasciatus (Bohemann, 1933) (Coleoptra, Bruchidae) em Phaseolus vulgaris L., c.v. carioca (Fabaceae), sob condições de laboratório. Rev Bras Entomol 47: 621-624.

Schoeder HE, Gollash S, Moore A, Tabe LM, Craig S, Hardie DC, Chrispeels MJ, Spencer D, Higgins TJV 1995. Bean (alpha)-amylase inhibitor confers resistance to the pea weevil (Bruchus pisorum) in transgenic peas (Pisum sativum L). Plant Physiol 107: 1233-1239.

Tawaha AM, Turk MA 2003. Allelopathic effects of black mustard (Brassica nigra) on germination and growth of wild Barley (Hordeum spontaneum). J Agron Crop Sci 189: 298-303.
Viegas Jr C 2003. Terpenos com atividade inseticida: uma alternativa para o controle químico de insetos. Quim Nova 26: 390-400. 